\title{
Thyroid: biological actions of 'nonclassical' thyroid hormones
}

\section{Rosalba Senese*, Federica Cioffi ${ }^{1, *}$, Pieter de Lange, Fernando Goglia ${ }^{1}$ and Antonia Lanni}

Dipartimento di Scienze e Tecnologie Ambientali, Biologiche e Farmaceutiche, Seconda Università degli Studi di Napoli, Via Vivaldi 43, 81100 Caserta, Italy

'Dipartimento di Scienze e Tecnologie, Università degli Studi del Sannio, Via Port'Arsa 11, 82100 Benevento, Italy *(R Senese and $\mathrm{F}$ Cioffi contributed equally to this work)
Correspondence should be addressed to A Lanni Email antonia.lanni@unina2.it

\begin{abstract}
Thyroid hormones (THs) are produced by the thyroid gland and converted in peripheral organs by deiodinases. THs regulate cell functions through two distinct mechanisms: genomic (nuclear) and nongenomic (non-nuclear). Many TH effects are mediated by the genomic pathway - a mechanism that requires $\mathrm{TH}$ activation of nuclear thyroid hormone receptors. The overall nongenomic processes, emerging as important accessory mechanisms in TH actions, have been observed at the plasma membrane, in the cytoplasm and cytoskeleton, and in organelles. Some products of peripheral TH metabolism (besides triiodo-L-thyronine), now termed 'nonclassical THs', were previously considered as inactive breakdown products. However, several reports have recently shown that they may have relevant biological effects. The recent accumulation of knowledge on how classical and nonclassical THs modulate the activity of membrane receptors, components of the mitochondrial respiratory chain, kinases and deacetylases, opened the door to the discovery of new pathways through which they act. We reviewed the current state-of-the-art on the actions of the nonclassical THs, discussing the role that these endogenous TH metabolites may have in the modulation of thyroid-related effects in organisms with differing complexity, ranging from nonmammals to humans.
\end{abstract}

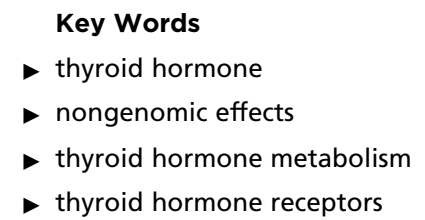

Key Words

- thyroid hormone metabolism

- thyroid hormone receptors

\section{Introduction}

\section{General notions}

The thyroid gland produces two main iodothyronines: tetraiodo-L-thyronine $\left(\mathrm{T}_{4}\right)$ and triiodo-L-thyronine $\left(\mathrm{T}_{3}\right)$. In humans, $\mathrm{T}_{4}$ is synthesized entirely within the thyroid and acts as a pro-hormone to generate $\mathrm{T}_{3}$. Only $20 \%$ of the $\mathrm{T}_{3}$ in circulation is secreted directly by the gland itself. The remaining $T_{3}$ derives from the peripheral monodeiodination of $\mathrm{T}_{4}$. Deiodinase activity regulates the local and systemic availability of $\mathrm{T}_{3}$ and other iodothyronines. Thyroid hormone (TH) deiodination is mediated by three
Journal of Endocrinology (2014) 221, R1-R12 
increases water solubility of substrates, facilitating biliary and/or urinary clearance (Visser 1990). Decarboxylation and deamination of THs lead to the formation of the socalled acetic acid-TH analogs such as triiodothyroacetic (Triac) and tetraiodothyroacetic (Tetrac) acids (SiegristKaiser \& Burger 1994). Several transporters contribute to the uptake of TH into the peripheral tissue, including organic anion-transporting polypeptides (OATPs), L-type amino acid transporters, monocarboxylate transporters (MCT), and bile acid transporters see for a recent review: Visser (2013).

\section{TH actions}

THs regulate cell functions through two distinct mechanisms: genomic (nuclear) and nongenomic (nonnuclear). Most effects of TH are mediated by the genomic pathway - a mechanism that requires thyroid hormone activation of nuclear receptors (TRs). This leads to a conformational change allowing interaction with specific thyroid hormone responsive elements located on the promoters of THs target genes (Bassett et al. 2003, Moeller \& Broecker-Preuss 2011, Tata 2013, Pascual \& Aranda 2013), regulating transcription rate. TRs homodimerize or interact with other nuclear receptors such as the retinoic $\mathrm{X}$ receptor (Forman et al. 1992, Bogazzi et al. 1994). TRs belong to a large family of ligand-dependent transcription factors, which includes nuclear hormone receptors for vitamins, xenobiotics, and sex steroids (Weitzel \& Alexander Iwen 2011). They are termed as TR $\alpha$ and TR $\beta$ and are encoded by two genes ( $\alpha$ and $\beta$ ) located on two different chromosomes (Cheng 2000) that express differently in developing and adult tissues (Oetting \& Yen 2007, Cheng et al. 2010). Highest $\operatorname{Tr} \alpha 1$ (Thra) expression is in the brain, with lower levels in the kidney, skeletal muscle, lungs, heart, and liver, whereas $\operatorname{Tr} \beta 1$ is expressed predominantly in the kidneys and liver, and at lower levels in the brain, heart, thyroid skeletal muscle, lungs, and spleen (Williams 2000). TR $\beta$ isoforms are involved in lipid metabolism (Pramfalk et al. 2011) by reducing serum lipids (Johansson et al. 2005, Angelin \& Rudling 2010, Shoemaker et al. 2012). TR $\beta$ disruption in mice impairs fatty acid (FA) oxidation (Araki et al. 2009) even in the presence of TR $\alpha$ overexpression (Gullberg et al. 2000, 2002). TR $\beta$ agonists have approximately tenfold greater affinity for TR $\beta$ than $\mathrm{TR} \alpha$, with a marked effect on the liver and efficacy in lowering of cholesterol (Webb 2010, Ladenson 2011). Although $T_{3}$ exerts many of its actions through canonical transcriptional regulation, an increasing amount of evidence shows that many of $\mathrm{T}_{3}$ effects are initiated outside the nucleus and involve different signaling transduction pathways. These effects are mediated by nongenomic actions. The overall nongenomic processes are poorly understood but emerge as important accessory mechanisms in $\mathrm{TH}$ actions and have been observed at the plasma membrane, in the cytoplasm and cytoskeleton, and in organelles (Wrutniak-Cabello et al. 2001, Cheng et al. 2010). Membrane receptors, consisting of specific integrin alpha V beta $3(\alpha \mathrm{V} \beta 3)$ receptors, have been identified (Bergh et al. 2005). THs on the cell surface trigger the serine-threonine kinase (MPK/ERK) pathway via the integrin receptor (Bergh et al. 2005, Cody et al. 2007), initiating complex cellular events (Lin et al. 2009a,b). In the cytoplasm, THs activate PI3K and thereby downstream gene transcription of specific genes. $\mathrm{T}_{3}$ also activates PI3K from the integrin $\alpha \mathrm{v} \beta 3$ hormone receptor site (Lin et al. 2009b, Moeller \& Broecker-Preuss 2011). Calcium is a second messenger regulated by THs through the modulation of a $\mathrm{Ca}^{2+}$-ATPase (Galo et al. 1981). Del Viscovo et al. (2012) showed that THs exert short-term nongenomic effects on intracellular calcium by modulating plasma membrane and mitochondrial pathways in rat pituitary GH3 cells. Furthermore, cellular actions involving Akt/protein kinase B (shown in human fibroblasts; Moeller et al. 2005) and AMP-activated protein kinase (AMPK) (in mice) (Irrcher et al. 2008) are well known. De Lange et al. (2008) showed that in rat skeletal muscle, $T_{3}$ stimulates FA and glucose metabolism through rapid activation of AMPK and Akt/protein kinase B signal transduction.

THs regulates mitochondrial activity and thus it may perhaps not be surprising that the mitochondria themselves are important target for THs. THs modulate mitochondrial activity through two ways: direct or indirect. The first requires the presence inside the organelles of specific binding sites for THs that play important physiological roles in regulation of the mitochondrial transcription apparatus (see for review, Cioffi et al. (2013)). One of these binding sites, termed p43, has been identified as a bona fide TR that binds to the D-loop region that contains the promoters of the mitochondrial genome (Wrutniak et al. 1995). By contrast, the indirect way acts through increased, nuclear TR-dependent transcription of factors that modulate the expression of mitochondrial genes (see for review, Cioffi et al. (2013)).

\section{The nonclassical THs}

Besides $T_{3}$, nonclassical THs exist. In the present review, we summarize the highlights of their biological actions.

Published by Bioscientifica Ltd 


\section{Tetrac and Triac}

In humans, the amount of Triac produced by the liver and other tissues accounts for about $14 \%$ of $\mathrm{T}_{3}$ metabolism (Siegrist-Kaiser \& Burger 1994). Triac is weakly TR $\beta$ selective, with a 1.5-fold affinity for TR $\beta$ (Schueler et al. 1990). Triac has been used to suppress thyroid-stimulating hormone (TSH) secretion in TH-resistant patients (Kunitake et al. 1989) and to increase metabolic rate in obese patients (Dumas et al. 1982). It has been shown to be more potent than $\mathrm{T}_{3}$ as both a $\beta$-adrenergic stimulator of uncoupling protein 1 and inducer of lipoprotein lipase mRNA, D3 activity, and mRNA (Medina-Gomez et al. 2003). Triac inhibits expression and secretion of leptin in rat primary white and brown adipocytes with a potency similar to that of $\mathrm{T}_{3}$ (Medina-Gomez et al. 2004). The use of Tetrac as a potential substitute for $\mathrm{T}_{4}$ has been studied in the treatment of myxedema and for its ameliorating effect on peripheral lipid metabolism in humans. The effects are similar to those of $\mathrm{T}_{4}$, but require higher dosing (Lerman 1956). Tetrac is currently used in the clinic for the treatment of TH resistance (Anzai et al. 2012). Therapeutic doses of Triac to treat pituitary and thyroid disorders exceed those required for $\mathrm{T}_{4}$ and $\mathrm{T}_{3}$ (Sherman \& Ladenson 1992, Bracco et al. 1993), a property attributed to its short half-life in humans and rodents (Pittman et al. 1980, Moreno et al. 1994). Classic THs are transported within the cell by TH transporters (Visser 2013). Tetrac does not seem to depend on active transport, at least by the most abundant transporter MCT8. Tetrac can replace $\mathrm{T}_{3}$ to restore normal fetal mouse brain development in MCT8null mice (Horn et al. 2013).

\section{Thyronamines}

The structures of the thyronamines (TAMs), a novel class of endogenous thyroid-signaling molecules, differ from $\mathrm{T}_{4}$ and deiodinated $\mathrm{TH}$ derivatives by the absence of a carboxylate group on the alanine side chain. 3-Iodothyronamine (T1AM) and TOAM have been detected in vivo (Scanlan et al. 2004, DeBarber et al. 2008) in the serum of rodents and humans (Saba et al. 2010, Hoefig et al. 2011), in rat liver, brain, and heart (Chiellini et al. 2007, Saba et al. 2010). Data from Piehl et al. (2008) present a role for deiodinases in TAM biosynthesis, defining biosynthetic pathways for T1AM and T0AM with $\mathrm{T}_{4}$ as a pro-hormone. Seemingly in contrast, a recently developed method to detect T1AM and T0AM in tissues and plasma (Ackermans et al. 2010) failed to reproduce the above data. Using rats treated with (13)C-labeled $\mathrm{T}_{4}$, the authors could detect in vivo conversion of $\mathrm{T}_{4}$ to $\mathrm{T}_{3}$ but not to $\mathrm{T} 1 \mathrm{AM}$ in plasma or brain samples, neither any endogenous T1AM nor T0AM was detected in the plasma from rats and plasma and in thyroid tissue from humans. Indeed, iodothyronine decarboxylation to iodothyronamines has not been demonstrated directly, and the aromatic amino acid decarboxylase was shown to be unable to catalyze iodothyronine decarboxylation (Hoefig et al. 2012). In line with this, data from Hackenmueller et al. (2012) suggest that T1AM is not an extrathyroidal metabolite of $\mathrm{T}_{4}$, yet is produced within the thyroid by a process that requires a sodium-iodide symporter and thyroperoxidase, the same biosynthetic factors necessary for $\mathrm{T}_{4}$ synthesis. These data shed new light on the pathways potentially involved in T1AM production and imply that the enzymatic conversion of iodothyronine to iodothyronamine is not simple. Steady-state physiological T1AM serum concentrations are similar to those of $\mathrm{T}_{3}$, and tissue concentrations of its metabolite, TOAM, exceed $\mathrm{T}_{4}$ and $\mathrm{T}_{3}$ metabolites by two- and 20-fold respectively (Hart et al. 2006, Chiellini et al. 2007). Physiological receptor(s) of TAMs remain to be identified. In TR receptor binding/gene activation assays, T1AM showed no affinity for TR $\beta$ and $\mathrm{TR} \alpha$, and inability to modulate nuclear TR-mediated transactivation (Chiellini et al. 1998). Studies surrounding TAM association with other receptors concluded that neither TOAM nor 3-T1AM activated Gas-coupled dopamine D1 and $\beta 2$ adrenergic receptors (Scanlan et al. 2004). T1AM, however, was found to be a potent agonist of trace amine-associated receptor 1 (TAAR1), an orphan $G$ protein-coupled receptor (Zucchi et al. 2006). Rat and mouse TAAR1 are activated by T1AM, with EC50 values of 14 and $112 \mathrm{nM}$ respectively. The T1AM ligand pharmacophore that activates TAAR1 was later characterized (Hart et al. 2006, Tan et al. 2007, 2008, Snead et al. 2008). T1AM reduces activation of the proto-oncogene c-fos (Manni et al. 2012). Ianculescu et al. (2009) reported that the cellular uptake of T1AM occurs via specific, saturable, and inhibitable transport mechanisms that are sodium and chloride independent, $\mathrm{pH}$ dependent, TAM specific, and do not involve candidate transporters of monoamines, organic cations, or THs. By a novel RNAi screening method, eight transporters of interest were identified. Knockdown resulted in T1AM transport in HeLa cells, but the physiological role of these transporters remains unknown. Studies using COS-1 cells transfected with multispecific OATPs, $1 \mathrm{~A} 2,1 \mathrm{~B} 3$, and $1 \mathrm{C} 1$, and the specific TH transporters, MCT8 and MCT10, proved that T1AM differentially inhibits $\mathrm{T}_{3}$ and $\mathrm{T}_{4}$ cellular uptake by these transporters (Ianculescu et al. 2010). Notably, T1AM

Published by Bioscientifica Ltd 
also inhibits both $\mathrm{T}_{3}$ and $\mathrm{T}_{4}$ uptake via MCT8, the most specific $\mathrm{TH}$ transporter. T1AM has no effect on $\mathrm{TH}$ transport by OATP1B3 and MCT10.

In mice, Scanlan et al. (2004) showed that a single i.p. injection of T1AM rapidly induced an $\sim 10^{\circ} \mathrm{C}$ drop in body temperature that peaked $1 \mathrm{~h}$ after injection and dose dependently disappeared after $4-6 \mathrm{~h}$. The same authors further showed that $\mathrm{T} 1 \mathrm{AM}$ reduction on cardiac performance was a direct effect and independent of T1AM-induced hypothermia. In a rat working heart preparation held at $37^{\circ} \mathrm{C}$, introduction of T1AM into the perfusion buffer resulted in large and immediate decreases in both heart rate and systolic aortic pressure. Additional studies on the heart have further supported direct actions of T1AM on this organ (Chiellini et al. 2007, Frascarelli et al. 2008). A single i.p. dose of T1AM dramatically switched fuel utilization away from carbohydrates and toward lipids (Braulke et al. 2008). Siberian hamsters (Phodopus sungorus), a hibernating rodent species, and mice completely shifted their respiratory quotients (RQ) from a normal, mixed carbohydrate and lipid value $(0.90$ for hamsters and 0.83 for mice) to a complete and persistent lipid-related RQ value of $\sim 0.7$ with elevated urine ketone content. The RQ effect ( $4.5 \mathrm{~h}$ after injection) lagged behind hypothermia, bradycardia, or hyperglycemia ( $1 \mathrm{~h}$ after injection). I.v. infusion with a low T1AM dose $(0.5 \mathrm{mg} / \mathrm{kg})$ into nonfasted naive rats rapidly increased endogenous glucose production and plasma glucose, plasma glucagon, and corticosterone, but did not affect plasma insulin (Klieverik et al. 2009). Contrastingly, in i.c.v. injected (130 ng/100 g body weight (BW)) shortterm fasted male mice (Manni et al. 2012), T1AM failed to ameliorate lipid profiles. It is known to possess a central effect, namely hypophagia, as well as peripheral effects of raised plasma glucose levels and reduced peripheral insulin sensitivity (the latter being also seen after i.p. injection (Braulke et al. 2008, Klieverik et al. 2009)), accompanied by pancreatic insulin production. Plasma free $\mathrm{T}_{3}$ ( $\mathrm{fT}_{3}$ ) levels were also lowered. Nonfasted, drugnaive rats (Klieverik et al. 2009) treated with T1AM $(100 \mu \mathrm{g} / \mathrm{kg})$ acutely increased endogenous glucose production and hyperglucagonemia, while (in contrast to the effect in fasted mice (Manni et al. 2012)) plasma insulin decreased. TOAM had a similar effect that was less profound (Klieverik et al. 2009). Interestingly, T1AM injection in mice resulted in $12 \%$ of the injected dose in the plasma, highlighting its systemic bioavailability (Manni et al. 2012). Inhibition of T1AM conversion by pretreatment with a mitochondrial amine oxidase inhibitor, clorgyline $(250 \mu \mathrm{g} / 100 \mathrm{~g} \mathrm{BW})$, prominently increased T1AM serum levels, but prevented the hyperglycemia and reduction of $\mathrm{fT}_{3}$ levels. This led the authors to indicate that a metabolite of T1AM causes these adverse effects. Central effects of T1AM administration also included amelioration of memory and reduction in pain threshold (Manni et al. 2013). T1AM's enhancing effect on learning renders this compound useful in the treatment of neurodegenerative diseases.

\section{3,3', $5^{\prime}$-Triiodo-L-thyronine}

$3,3^{\prime}, 5^{\prime}-\mathrm{T}_{3}$ (reverse $\mathrm{T}_{3}$, abbreviated as $\mathrm{rT}_{3}$ ), a product of 5-deiodination of $\mathrm{T}_{4}$ by $\mathrm{D} 1$ and $\mathrm{D} 3$, is a potent initiator of actin polymerization in astrocytes. It portrays similar effectiveness to $\mathrm{T}_{4}$ and much more than $\mathrm{T}_{3}$ (Farwell et al. 2006). In hypothyroid rodents, neurons and astrocytes develop poor actin cytoskeletons that $\mathrm{T}_{3}$ replacement cannot rescue. However, $\mathrm{rT}_{3}$ initiates reappearance of filamentous actin within minutes without altering total actin mRNA or protein content (Farwell et al. 1990, Siegrist-Kaiser et al. 1990). This $\mathrm{rT}_{3}$ property is attributed to TR $\Delta \alpha 1$, a native TR isoform that lacks a nuclear localization signal and is present in the extranuclear compartment of astrocytes and neurons. This isoform has the ligand affinity and specificity required for of actin polymerization by $\mathrm{rT}_{3}$. A study of the astrocytes of the developing mouse cerebellum deprived of both TRs showed that TR $\Delta \alpha 1$ rescued the actin cytoskeleton's response to $\mathrm{rT}_{3}$ (Flamant \& Samarut 2003). Thus, THs may require TR regions that are not necessarily canonical DNA-binding regions. $\mathrm{rT}_{3}$ also inhibits free FA levels in chickens stimulated with dexamethasone or adrenaline (Bobek et al. 2002).

\section{3,5-Diiodo-L-thyronine}

Several studies have indicated 3,5-diiodo-L-thyronine $\left(\mathrm{T}_{2}\right)$, an endogenous metabolite of $T_{3}$, as a peripheral mediator of several TH metabolic effects. Although conversion of $\mathrm{T}_{3}$ to $\mathrm{T}_{2}$ has not been demonstrated in vitro, indirect evidence indicates that $\mathrm{T}_{2}$ is indeed formed from $\mathrm{T}_{3}$ in vivo through deiodination (Moreno et al. 2002). Serum concentrations of $\mathrm{T}_{2}$ in humans are within the picomolar range $(16 \mathrm{pM}$ in healthy individuals to $50 \mathrm{pM}$ maximum in individuals with nonthyroidal illness; Pinna et al. 1997). Rat intra-hepatic $T_{2}$ concentrations are $1.5 \mathrm{fmol} / 100 \mathrm{mg}$ (Moreno et al. 2002). To date, results in hypothyroid rats suggest that $\mathrm{T}_{2}$ has specific actions on resting metabolic rate (RMR) that are distinct from those of $\mathrm{T}_{3}$ : they are more rapid and not attenuated by actinomycin D (see Fig. 1A and B; Lanni et al. 1996).

Published by Bioscientifica Ltd 

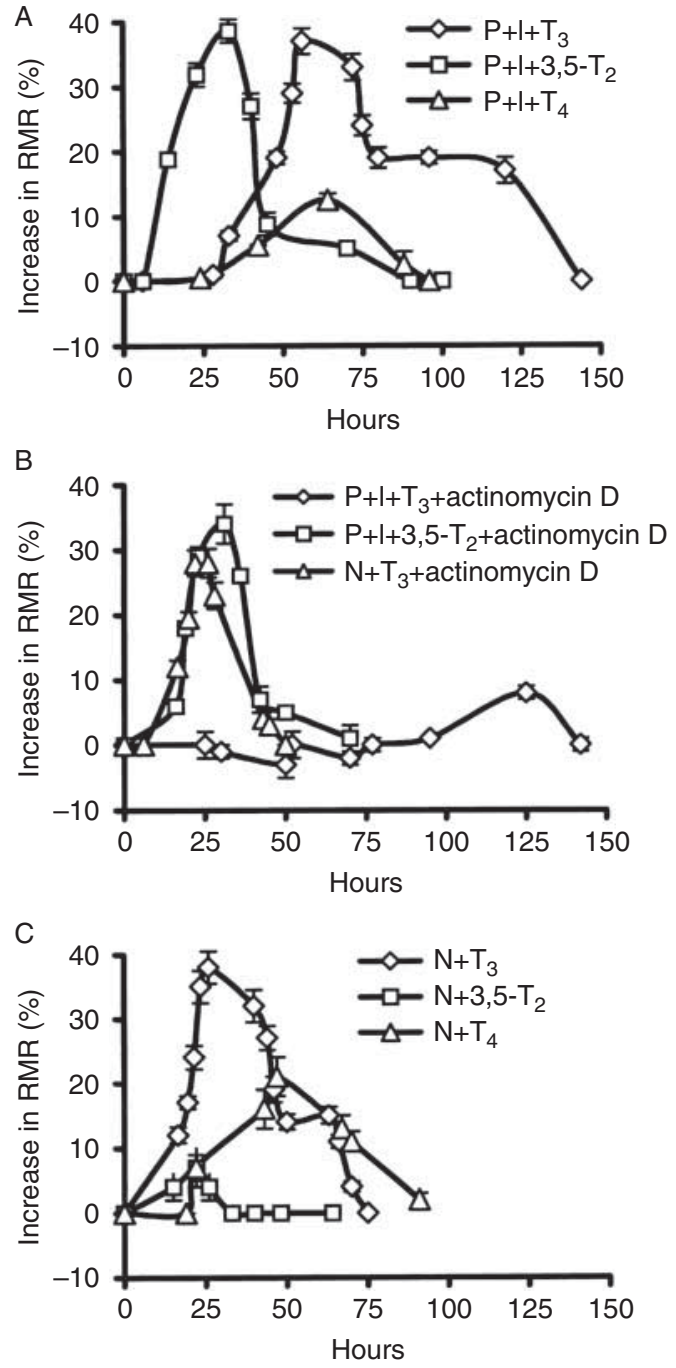

\section{Figure 1}

Changes in RMR in hypothyroid $(\mathrm{P}+\mathrm{I})$ and euthyroid $(\mathrm{N})$ rats after administration of $T_{4}, T_{3}$, and the nonclassical thyroid hormone $T_{2}$, with or without simultaneous administration of actinomycin D. (A) Hypothyroidism was chronically induced by combined treatment of propylthiouracil (PTU) and IOP $(\mathrm{P}+\mathrm{I}) . \mathrm{N}$ and $\mathrm{P}+\mathrm{I}$ rats were acutely injected with $25 \mu \mathrm{g}$ iodothyronine/100 $\mathrm{g}$ body weight (BW). Each data-point shows the mean \pm S.E.M. from four rats. Values are expressed as a percent change from the value at time 0 (i.e. immediately before injection). Actual RMRs $(\mathrm{IO} 2 \mathrm{~kg} / 0.75 \mathrm{per} \mathrm{h})$ at time 0 were $1.01 \pm 0.12,0.99 \pm 0.10$, and $0.94 \pm 0.08$ for $\mathrm{P}+\mathrm{I}+\mathrm{T}_{3}, \mathrm{P}+\mathrm{I}+3,5-\mathrm{T}_{2}$, and $\mathrm{P}+\mathrm{I}+\mathrm{T}_{4}$ groups respectively. (B) Actinomycin $D(8 \mu \mathrm{g} / 100 \mathrm{~g} \mathrm{BW})$ was injected in combination with $25 \mu \mathrm{g} / 100 \mathrm{~g} \mathrm{BW}$ of either $\mathrm{T}_{3}$ or $3,5-\mathrm{T}_{2}$. Each data-point is the mean \pm S.E.M. from four rats. Values are expressed as a percent change from the time 0 value (i.e. immediately before injection). Actual RMRs $\left(\mathrm{IO}_{2} / \mathrm{kg}^{0.75} / \mathrm{h}\right)$ at time 0 were $1.06 \pm 0.15,0.98 \pm 0.12$, and $1.44 \pm 0.04$ for $P+I+T_{3}+$ actinomycin $D, P+I+$ 3,5- $\mathrm{T}_{2}+$ actinomycin $\mathrm{D}$, and $\mathrm{N}+\mathrm{T}_{3}+$ actinomycin $\mathrm{D}$ groups respectively. (C) RMRs (IO2 kg/0.75 per h) at time 0 were $1.41 \pm 0.03,1.39 \pm 0.04$, and $1.42 \pm 0.03$ for $\mathrm{N}+\mathrm{T}_{3}, \mathrm{~N}+3,5-\mathrm{T}_{2}$, and $\mathrm{N}+\mathrm{T}_{4}$ groups respectively. Figure adapted from Moreno et al. (2002), republication approved by the Endocrine Society.
$\mathrm{T}_{3}$ injection to euthyroid animals resulted in combined $\mathrm{T}_{3}$ and $\mathrm{T}_{2}$ patterns on RMR (see Fig. $1 \mathrm{C}$ ). $\mathrm{T}_{3}$, propylthiouracil (inhibiting type 1 deiodinase and thyroid peroxidase activity), and iopanoic acid (inhibiting the activity of all three deiodinases) combined treatment showed a long-term induction of RMR. $\mathrm{T}_{2}$ is thus predominantly responsible for short-term induction of RMR (Fig. 1A; Moreno et al. 2002). The metabolic effects of $\mathrm{T}_{2}$ also underlined the ability of this hormone to improve survival of hypothyroid rats to cold with persistent increased energy expenditure (Lanni et al. 1998). Furthermore, upon $\mathrm{T}_{2}$ administration to hypothyroid rats, the RMR and FA oxidation increases in the muscle mitochondria are accompanied by mitochondrial translocation of the FA transporter FAT/CD36, ensuring effective increases in metabolic rate (Lombardi et al. 2012). Several data support the ability of $\mathrm{T}_{2}$ to stimulate mitochondrial activities in a very rapid manner (Lanni et al. 1992, 1993, 1994, Goglia 2005, Cavallo et al. 2011), excluding short-term genomic action of $\mathrm{T}_{2}$. Chronic treatment of hypothyroid rats with $T_{2}$ revealed a different picture: $T_{2}$ upregulated protein levels of ATP synthase subunits (alpha, beta, F(o)I-PVP, and OSCP; Mangiullo et al. 2010). Increase in $\beta$-subunit mRNA accumulation suggested indirect transcriptional regulation by $\mathrm{T}_{2}$ through activation of the transcription factor, GA-binding protein/nuclear respiratory factor-2 (Mangiullo et al. 2010). Moreover, D1 activity in the rat anterior pituitary has been shown to be increased transiently after a single injection of $\mathrm{T}_{2}$, while in a reaggregate culture of anterior pituitary, $\mathrm{T}_{2}$ has been demonstrated to stimulate D1 at $24 \mathrm{~h}$ after its application, dose dependently (Baur et al. 1997).

$\mathrm{T}_{2}$, as a nonclassical $\mathrm{TH}$, is able to prevent $\mathrm{BW}$ gain when administered i.p. to rats fed a high-fat diet without inducing $\mathrm{T}_{3}$-related undesirable side effects (tachycardia, cardiac hyperplasia, and decreased TSH levels), at least at the administered dose $(25 \mu \mathrm{g} / 100 \mathrm{~g}$ BW for 4 weeks) (Lanni et al. 2005, De Lange et al. 2011, Moreno et al. 2011). At this dose, by almost doubling hepatic FA oxidation rate, $\mathrm{T}_{2}$ efficiently prevented HFD-induced i) hepatic fat accumulation, ii) insulin resistance, and iii) increase in serum triglycerides (TGs) and cholesterol levels (Lanni et al. 2005). $\mathrm{T}_{2}$ stimulated mitochondrial uncoupling, decreased ATP synthesis, and increased fat burning, thus counteracting obesity (Lanni et al. 2005).

An important consequence of the above-described effects of $\mathrm{T}_{2}$ included increased skeletal muscle insulin sensitivity, due to an increased response to insulin of Akt/PKB phosphorylation, and sarcolemmal glucose transporter 4 accumulation (Moreno et al. 2011). Importantly, $\mathrm{T}_{2}$ also induced biochemical and structural shifts

Published by Bioscientifica Ltd 
toward glycolytic myofibers (Moreno et al. 2011). For an overview of $\mathrm{T}_{2}$ 's effects on metabolism, see Fig. 2. Proteomic analysis of intracellular and mitochondrial proteins (Silvestri et al. 2010) revealed that mitochondria were the principal targets of $T_{2}$ 's normalizing effects on changes induced by high-fat diet (HFD). BN-page analysis revealed that $\mathrm{T}_{2}$ partially restored individual OXPHOS complex (predominantly complexes I and II) levels induced by HFD. Additionally, $\mathrm{T}_{2}$ augmented the activities of respiratory complexes, with respect to both HFD (except complex V) and $\mathrm{N}$ animals (except complex IV). In rats pre-fed a HFD, subsequent $\mathrm{T}_{2}$ administration reduced hepatic fat and hyperlipidemia via the same biochemical pathways described previously (Mollica et al. 2009).
$\mathrm{T}_{2}$ carries out its antilipidemic effects via activation of two important factors involved in lipid metabolism: AMPK and nuclear deacetylase sirtuin 1 (SIRT1). AMPK is a known sensor of cellular ATP levels (Ruderman et al. 2013), and SIRT1 regulates metabolic balance in response to increases in cellular $\mathrm{NAD}^{+}: \mathrm{NADH}$ ratios. It has recently been identified to be a crucial target abating, diet-induced obesity in rodents (Rodgers et al. 2005, Lagouge et al. 2006, Gerhart-Hines et al. 2007). After simultaneous administration to rats receiving a high-fat diet, rapid induction of hepatic FA oxidation by $\mathrm{T}_{2}$ (within $6 \mathrm{~h}$ ) was concomitant with hepatic activation of SIRT1, an activity persisting over time. Increased phosphorylation of AMPK was observed after 4 weeks of treatment (De Lange et al. 2011).
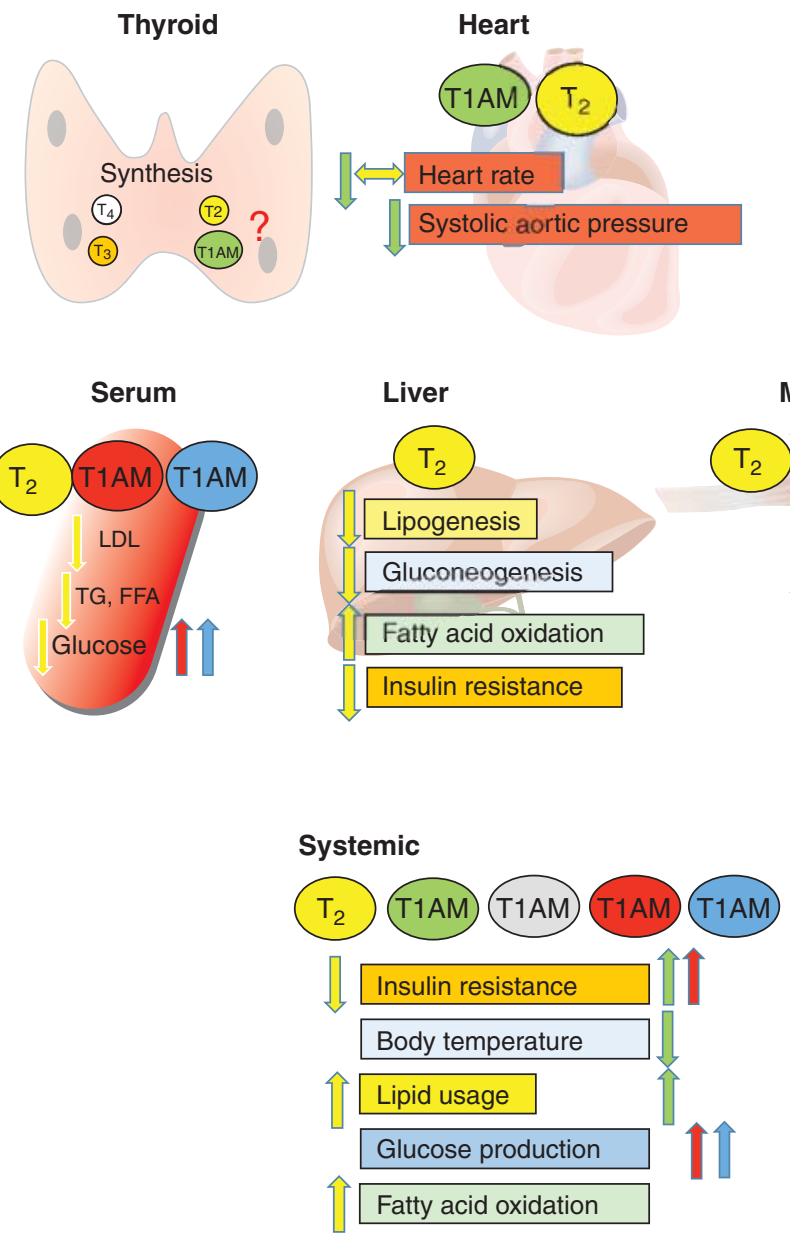

Brain

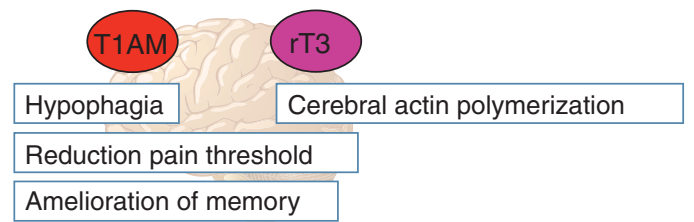

Muscle
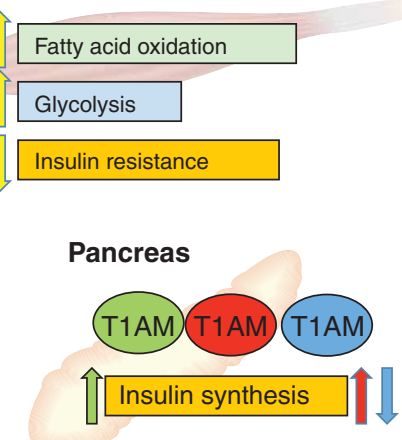

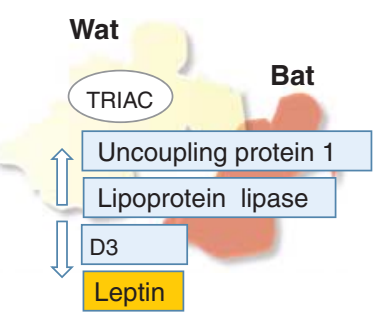

Figure 2

Thyroid synthesis of thyroid hormones (THs) and administration effects of nonclassical THs. Question mark, thyroid synthesis of $T_{2}$ and T1AM is currently still under debate. Peripheral synthesis of nonclassical THs by deiodinase activity (see text) is not indicated. Administration of nonclassical THs (for explanations of treatments, see text) indicated in color. White, Triac incubation in rat primary cultures; yellow, i.p. administration

of $T_{2}$ in rats on a high-fat diet; green, i.p. or i.v. administration of T1AM in mice; grey, i.v. administration of T1AM in mice; red, i.c.v. administration of T1AM to fasted mice; blue, i.c.v. administration of T1AM to mice; and purple, $\mathrm{rT}_{3}$ administration to mice. Arrows pointing upward, upregulation; arrows pointing downward, downregulation; double horizontal arrows, no change; and absence of arrows, no effect reported to date. 
Induction of SIRT1 led to deacetylation of peroxisome proliferator-activated receptor $\gamma$ coactivator- $1 \alpha$ and sterol receptor element binding protein-1c (SREBP-1c), associated with induction and reduction of expression of genes involved in FA oxidation and lipogenesis respectively (De Lange et al. 2011). These findings provide a clue to explain $\mathrm{T}_{2}$ 's effectiveness in lowering hepatic fat accumulation and counteracting insulin resistance with respect to $T_{3}$. In a similar system, $T_{3}$ has increased hepatic lipogenesis (Cable et al. 2009).

A second clue indicating that $\mathrm{T}_{2}$ has contrasting effects on hepatic lipogenesis involving SREBP-1c was found in vitro. $\mathrm{T}_{3}$ increases an active precursor of SREBP-1c in HepG2 cells without modulating SREBP-1c transcription (Gnoni et al. 2012). $\mathrm{T}_{2}$, however, blocks proteolytic cleavage and thus activation of SREBP-1c (Rochira et al. 2013) independent of transcription. Consequently, FA synthase expression reduced. The resulting inhibitory effect of $\mathrm{T}_{2}$ on lipogenesis is concordant with in vivo findings (De Lange et al. 2011) and mechanistically complementary to SIRT1-dependent deacetylation of SREBP-1c (De Lange et al. 2011). The liver is not the only organ in which $T_{2}$ activates SIRT1: $T_{2}$ has been shown to act through SIRT1 activation in the kidney (Shang et al. 2013). Treatment with $\mathrm{T}_{2}$ prevented diabetic nephropathy (DN) in a diabetic rat model via SIRT1-dependent deacetylation and p65, a subunit of nuclear factor- $\mathrm{\kappa} \mathrm{B}$, inactivation, thus inhibiting the inflammatory process crucial to this pathology. In rat mesangial cells, the DN phenotype was induced by exposure to high glucose, and treatment with $\mathrm{T}_{2}$ under these conditions counteracted the DN phenotype. Co-treatment with $\mathrm{T}_{2}$ and sirtinol - a specific SIRT1 inhibitor (Shang et al. 2013) - abolished deacetylation of p65. $\mathrm{T}_{2}$ leads to dephosphorylation of JNK independent of SIRT1, and did not associate with abating the DN phenotype (Shang et al. 2013). Thus, SIRT1 activation plays a crucial role in $\mathrm{T}_{2}$ 's relieving effect on DN.

As a first step in projecting rodent data to study $T_{2}$ 's metabolic effects in humans, two healthy volunteers were administered $\mathrm{T}_{2}(1-4 \mu \mathrm{g} / \mathrm{kg} \mathrm{BW})$ acutely. After $6 \mathrm{~h}$, a significant increase in RMR was detected in both patients. Daily $_{2}$ administration for 28 days increased RMR by $\sim 15 \%$ and decreased $\mathrm{BW}$ by about $4 \mathrm{~kg}$. Ultrasonography revealed that one subject showed reductions in steatosis. Additionally, total serum cholesterol levels were lowered, and no side effects were recorded (Antonelli et al. 2011). A mechanism by which $T_{2}$ reduces cholesterol in the serum (Lanni et al. 2005, Antonelli et al. 2011, De Lange et al. 2011) was recently called into question. $T_{2}$ 's LDL-lowering effects are independent of the LDL receptor (Goldberg et al. 2012), as determined by feeding a western type diet to LDL receptor-deficient mice $\left(\mathrm{Ldll}^{-/-}\right)$and treating with $\mathrm{T}_{2}$. The diet was chosen because dietary absorption of cholesterol and TG drives hepatic apoB production, especially in $\mathrm{Ldll}^{-1-}$ mice. These mice develop much higher levels of cholesterol and atherosclerosis. $\mathrm{T}_{2}$ had no effect on TG levels, probably due to increased lipolysis, but led to marked reductions in liver apoB and circulating apoB48 and apoB100 (Goldberg et al. 2012).

To study whether the lipid-lowering effects of $\mathrm{T}_{2}$ were directly acting on the liver, or if they were secondary to changes in endocrine or metabolic pathways, primary rat hepatocytes, overloaded with lipids (to obtain 'fatty hepatocytes') and treated with $\mathrm{T}_{2}\left(10^{-5} \mathrm{M}\right)$ have been employed (Grasselli et al. 2011a). This experimental setup demonstrated that $T_{2}$ reversed the effects induced by lipid overload in these cells, thus supporting a direct effect of $\mathrm{T}_{2}$. Moreover, rat hepatoma (FAO) cells defective for functional TRs were used to answer whether $\mathrm{T}_{2}$-mediated lowering of hepatic lipid profiles even requires TR action (Grasselli et al. 2011b). Exposure to pharmacological doses of $\mathrm{T}_{2}\left(10^{-5} \mathrm{M}\right)$ for $24 \mathrm{~h}$ reversed the effects induced by FAs and increased mitochondrial uncoupling, thus indicating that the actions of $T_{2}$ in these cells are independent of transcriptionally functional TRs.

Intracellular action of $\mathrm{T}_{2}$ also is described in avian cells during fetal development and cell differentiation (Incerpi et al. 2002). $T_{2}$ regulates DNA synthesis, cell-cycle proteins (Alisi et al. 2004), and several membrane-associated transport systems, whose activity is related to cell proliferation (Incerpi et al. 2002, 2005). $\mathrm{T}_{2}$ 's effect on the $\mathrm{Na}^{+}-\mathrm{H}^{+}$exchanger was identified for 14-day- and 19-dayold cells, whereas the effect on amino acid transport was present at late stages of embryo development. Both transport systems were activated through a signal transduction pathway involving the PKC, MAPK, and PI3K pathways (Incerpi et al. 2002). Moreover, $\mathrm{T}_{2}$ exerts a short-term inhibitory effect on the $\mathrm{Na}^{+}-\mathrm{K}^{+}$-ATPase, the magnitude of which strongly correlates to the developmental age of the isolated cells (Scapin et al. 2009). The $\mathrm{Na}^{+}-\mathrm{K}^{+}$-ATPase inhibition is mediated through the activation of PKA, PKC, and PI3K (Scapin et al. 2009). Signal transduction pathways contributing to the modulation of the sodium pump by $\mathrm{T}_{2}$ are involved in the control exerted on cell proliferation.

Recently, it has been shown that $\mathrm{T}_{2}$ exerts short-term effects on intracellular calcium concentrations and NO release by modulating plasma membrane and mitochondrial pathways in pituitary GH3 cells (Del Viscovo et al. 2012). In particular, $\mathrm{T}_{2}$ facilitates physiological $\mathrm{Ca}^{2}$

Published by Bioscientifica Ltd 
Table 1 Involvement of TRs or alternative receptors in non-classical thyroid hormone action

\begin{tabular}{l}
$\begin{array}{l}\text { Non-classical } \\
\text { thyroid hormone }\end{array}$ \\
\hline Triac \\
T1AM \\
$\mathrm{rT}_{3}$ \\
$\mathrm{~T}_{2}$ \\
\hline
\end{tabular}

\section{Affinity for/transactivation through $\operatorname{TR} \alpha$ or $\operatorname{TR} \beta$}

High (Schueler et al. 1990)

Absent (Chiellini et al. 1998)

High $^{\text {a }}$ (TR $\Delta \alpha 1$ (native TR isoform); Flamant \& Samarut 2003)

Weak (human TR $\alpha$; Cioffi et al. 2010)

Weak (human TRß; Ball et al. 1997, Cioffi et al. 2010,

De Lange et al. 2011, Mendoza et al. 2013)

High (short TR $\beta$ of tilapia fish; Mendoza et al. 2013,

Navarrete-Ramirez et al. 2014)

\section{Affinity for other receptors}

None yet identified

High (trace amine-associated receptor 1

(TAAR1); Zucchi et al. 2006)

None yet identified

None yet identified

${ }^{a}$ Nongenomic action.

efflux from mitochondria through activation of mt-NCX by interacting with different mitochondrial complexes (Del Viscovo et al. 2012).

$\mathrm{T}_{2}$ 's biological effects are not restricted to mammalian species. Indeed, in the goldfish Carassius auratus, stimulation of pyruvate-fueled liver and muscle mitochondrial respiration was observed 5 min after $0.3 \mathrm{nM} \mathrm{T}_{2}$ incubation (Leary et al. 1996). García et al. (2004) examined the effects of short-term $\mathrm{T}_{4}, \mathrm{~T}_{3}$, and $\mathrm{T}_{2}$ exposure $(0.1 \mu \mathrm{M} ; 12$ or $24 \mathrm{~h})$ on D1 and D2 activities and mRNA in killifish (tilapia) liver and showed that these hormones decreased D2 activity, the effect of $\mathrm{T}_{2}$ being relatively more rapid. $\mathrm{T}_{2}$ also regulates thermal acclimation in zebra fish (Danio rerio) with an efficiency comparable to $T_{3}$ (Little et al. 2013). The conserved role for $\mathrm{T}_{2}$ on regulating metabolic efficiency in many species validates the motion to learn more about biological actions of this nonclassical $\mathrm{TH}$.

\section{Mechanism of action of $T_{2}$}

Questions surrounding the cellular-molecular mechanism of action of $\mathrm{T}_{2}$ remain. Both TR- and non TR-mediated actions may be elicited by $\mathrm{T}_{2}$. Ball et al. (1997) reported that $\mathrm{T}_{2}$ exerted selective thyromimetic effects. In the same report, $\mathrm{T}_{2}$ showed a 60 times weaker affinity for TR $\beta$ than $\mathrm{T}_{3}$. Mendoza et al. (2013) reported that in teleosts, effects of $\mathrm{T}_{2}$ may be mediated by an isoform of one of the two known TR $\beta$ s, namely TR $\beta 1$ that contains a 9-amino-acid insert in its ligand-binding domain (long TR $\beta 1$ ), whereas $\mathrm{T}_{3}$ binds preferentially to a short TR $\beta 1$ isoform lacking this insert. Moreover, the authors confirmed that $\mathrm{T}_{2}$ has a weak affinity for human TR $\beta$ (about 40-fold less than $\mathrm{T}_{3}$ ) and a similarly weak transactivation capacity compared with $\mathrm{T}_{3}$ (Ball et al. 1997, Cioffi et al. 2010, De Lange et al. 2011, Mendoza et al. 2013). In tilapia, both $T_{3}$ and $T_{2}$ are important in growth, a process, however, mediated by different TR $\beta 1$ isoforms (Navarrete-Ramirez et al. 2014). An overview of TR or alternative receptor involvement in the action of nonclassical THs is shown in Table 1.

Non TR-mediated effects of $\mathrm{T}_{2}$ are evident. It is known that $\mathrm{T}_{2}$ specifically stimulates the activity of isolated cytochrome $c$ oxidase (COX) from bovine heart mitochondria. $\mathrm{T}_{3}$ barely stimulates $\mathrm{COX}$. $\mathrm{T}_{2}$ binding to COX induces conformational changes. Studies show specific binding of labeled $\mathrm{T}_{2}$ to the subunit $\mathrm{Va}$ of COX from bovine heart. $T_{2}$, and to a small extent $T_{3}$, but not thyroxine and thyronine, abolished allosteric inhibition of ascorbate respiration of reconstituted COX by ATP. Inhibition is rescued by a monoclonal antibody to the subunit Va. (Goglia et al. 1994, Arnold et al. 1998). $\mathrm{T}_{2}$ directly activates SIRT1 (De Lange et al. 2011), influencing downstream pathways and inducing benefits. Shang et al. (2013) showed that this interaction mitigates a DN by using the Sirtuin inhibitor Sirtinol.

\section{Conclusion and perspectives}

It is clear that the so-called 'nonclassical THs' can induce various biological actions. TH derivatives exert important actions on metabolic parameters and on growth. At the cellular-molecular level, several pathways are affected, the most intriguing of which are related to lipid metabolism and signaling pathways. Beneficial effects of these molecules require more considerations due to their potential to modulate human health.

\section{Declaration of interest}

The authors declare that there is no conflict of interest that could be perceived as prejudicing the impartiality of the review.

Published by Bioscientifica Ltd. 


\section{Funding}

This work has been supported, in part, by the following grants: MIUR COFIN 2006 Prot. 2006051517 and MIUR COFIN 2008 Prot. 20089SRS2X.

\section{References}

Ackermans MT, Klieverik LP, Ringeling P, Endert E, Kalsbeek A \& Fliers E 2010 An online solid-phase extraction-liquid chromatography-tandem mass spectrometry method to study the presence of thyronamines in plasma and tissue and their putative conversion from 13C6-thyroxine. Journal of Endocrinology 206 327-334. (doi:10.1677/JOE-10-0060)

Alisi A, Spagnuolo S, Napoletano S, Spaziani A \& Leoni S 2004 Thyroid hormones regulate DNA-synthesis and cell-cycle proteins by activation of PKC $\alpha$ and p42/44 MAPK in chick embryo hepatocytes. Journal of Cellular Physiology 201 259-265. (doi:10.1002/jcp.20060)

Angelin B \& Rudling M 2010 Lipid lowering with thyroid hormone and thyromimetics. Current Opinion in Lipidology 21 499-506. (doi:10.1097/ MOL.0b013e3283402e9c)

Antonelli A, Fallahi P, Ferrari SM, Di Domenicantonio A, Moreno M, Lanni A \& Goglia F 2011 3,5-Diiodo-L-thyronine increases resting metabolic rate and reduces body weight without undesirable side effects. Journal of Biological Regulators and Homeostatic Agents 25 655-660.

Anzai R, Adachi M, Sho N, Muroya K, Asakura Y \& Onigata K 2012 Long-term $3,5,3^{\prime}$ triiodothyroacetic acid therapy in a child with hyperthyroidism caused by thyroid hormone resistance: pharmacological study and therapeutic recommendations. Thyroid $\mathbf{2 2}$ 1069-1075. (doi:10.1089/thy.2011.0450)

Araki O, Ying H, Zhu XG, Willingham MC \& Cheng SY 2009 Distinct dysregulation of lipid metabolism by unliganded thyroid hormone receptor isoforms. Molecular Endocrinology 23 308-315. (doi:10.1210/ me.2008-0311)

Arnold S, Goglia F \& Kadenbach B 1998 3,5-Diiodothyronine binds to subunit Va of cytochrome- $c$ oxidase and abolishes the allosteric inhibition of respiration by ATP. European Journal of Biochemistry 252 325-323. (doi:10.1046/j.1432-1327.1998.2520325.x)

Ball SG, Sokolov J \& Chin WW 1997 3,5-Diiodo-L-thyronine $\left(\mathrm{T}_{2}\right)$ has selective thyromimetic effects in vivo and in vitro. Journal of Molecular Endocrinology 19 137-147. (doi:10.1677/jme.0.0190137)

Bassett JH, Harvey CB \& Williams GR 2003 Mechanisms of thyroid hormone receptor-specific nuclear and extra nuclear actions. Molecular and Cellular Endocrinology 213 1-11. (doi:10.1016/j.mce.2003.10.033)

Baur A, Bauer K, Jarry H \& Koehrle J 1997 3,5-Diiodo-L-thyronine stimulates type $15^{\prime}$ deiodinase activity in rat anterior pituitaries in vivo and in reaggregate cultures and GH3 cells in vitro. Endocrinology 138 3242-3248. (doi:10.1210/endo.138.8.5333)

Bergh JJ, Lin HY, Lansing L, Mohamed SN, Davis FB, Mousa S \& Davis P 2005 Integrin $\alpha \mathrm{V} \beta 3$ contains a cell surface receptor site for thyroid hormone that is linked to activation of mitogen-activated protein kinase and induction of angiogenesis. Endocrinology 146 2864-2871. (doi:10.1210/en.2005-0102)

Bianco AC 2011 Minireview: cracking the metabolic code for thyroid hormone signaling. Endocrinology 152 3306-3311. (doi:10.1210/ en.2011-1104)

Bobek S, Sechman A, Niezgoda J \& Jacek T 2002 Reverse 3,3', 5' triiodothyronine suppresses increase in free fatty acids in chickens elicited by dexamethasone or adrenaline. Journal of Veterinary Medicine. A, Physiology, Pathology, Clinical Medicine 49 121-124. (doi:10.1046/ j.1439-0442.2002.00343.x)

Bogazzi F, Hudson LD \& Nikodem VM 1994 A novel heterodimerization partner for thyroid hormone receptor. Peroxisome proliferator activated receptor. Journal of Biological Chemistry 269 11683-11686.

Bracco D, Morin O, Schutz Y, Liang H, Jequier E \& Burger AG 1993 Comparison of the metabolic and endocrine effects of 3,5, $3^{\prime}$-triiodothyroacetic acid and thyroxine. Journal of Clinical Endocrinology and Metabolism $\mathbf{7 7}$ 221-228. (doi:10.1210/jcem.77.1.8325946)

Braulke LJ, Klingenspor M, DeBarber A, Tobias SC, Grandy DK, Scanlan TS \& Heldmaier G 2008 3-Iodothyronamine: a novel hormone controlling the balance between glucose and lipid utilisation. Journal of Comparative Physiology. B, Biochemical, Systemic, and Environmental Physiology 178 167-177. (doi:10.1007/s00360-007-0208-x)

Cable EE, Finn PD, Stebbins JW, Hou J, Ito BR, van Poelje PD, Linemeyer DL \& Erion MD 2009 Reduction of hepatic steatosis in rats and mice after treatment with a liver-targeted thyroid hormone receptor agonist. Hepatology 49 407-417.

Cavallo A, Gnoni A, Conte E, Siculella L, Zanotti F, Papa S \& Gnoni GV 2011 3,5-Diiodo-L-thyronine increases FoF1-ATP synthase activity and cardiolipin level in liver mitochondria of hypothyroid rats. Journal of Bioenergetics and Biomembranes 43 349-357. (doi:10.1007/ s10863-011-9366-3)

Cheng SY, Leonard JL \& Davis PJ 2010 Molecular aspects of thyroid hormone actions. Endocrine Reviews 31 139-170. (doi:10.1210/er.20090007)

Cheng SY 2000 Multiple mechanisms for regulation of the transcriptional activity of thyroid hormone receptors. Reviews in Endocrine and Metabolic Disorders 1 9-18.

Chiellini G, Apriletti JW, Yoshihara HA, Baxter JD, Ribeiro RC \& Scanlan TS 1998 A high-affinity subtype-selective agonist ligand for the thyroid hormone receptor. Chemistry \& Biology 5 299-306. (doi:10.1016/ S1074-5521(98)90168-5)

Chiellini G, Frascarelli S, Ghelardoni S, Carnicelli V, Tobias SC, DeBarber A, Brogioni S, Ronca-Testoni S, Cerbai E, Grandy DKetal. 2007 Cardiac effects of 3-iodothyronamine: a new aminergic system modulating cardiac function. FASEB Journal 21 1597-1608. (doi:10.1096/fj.06-7474com)

Cioffi F, Zambad SP, Chhipa L, Senese R, Busiello RA, Tuli D, Munshi S, Moreno M, Lombardi A, Gupta RC et al. 2010 TRC150094, a novel functional analog of iodothyronines, reduces adiposity by increasing energy expenditure and fatty acid oxidation in rats receiving a high-fat diet. FASEB Journal 24 3451-3461. (doi:10.1096/fj.10-157115)

Cioffi F, Senese R, Lanni A \& Goglia F 2013 Thyroid hormones and mitochondria: with a brief look at derivatives and analogues. Molecular and Cellular Endocrinology 379 51-61. (doi:10.1016/j.mce.2013.06.006)

Cody V, Davis PJ \& Davis FB 2007 Molecular modeling of the thyroid hormone interactions with $\alpha \mathrm{v} \beta 3$ integrin. Steroids 72 165-170. (doi:10.1016/j.steroids.2006.11.008)

DeBarber AE, Geraci T, Colasurdo VP, Hackenmueller SA \& Scanlan TS 2008 Validation of a liquid chromatography-tandem mass spectrometry method to enable quantification of 3-iodothyronamine from serum. Journal of Chromatography. A $\mathbf{1 2 1 0} 55-59$. (doi:10.1016/j.chroma. 2008.09.022)

De Lange P, Senese R, Cioffi F, Moreno M, Lombardi A, Silvestri E, Goglia F \& Lanni A 2008 Rapid activation by 3,5,3'-L-triiodothyronine of adenosine $5^{\prime}$-monophosphate-activated protein kinase/acetylcoenzyme a carboxylase and akt/protein kinase B signaling pathways: relation to changes in fuel metabolism and myosin heavy-chain protein content in rat gastrocnemius muscle in vivo. Endocrinology 149 6462-6470. (doi:10.1210/en.2008-0202)

De Lange P, Cioffi F, Senese R, Moreno M, Lombardi A, Silvestri E, De Matteis R, Lionetti L, Mollica MP, Goglia F et al. 2011 Nonthyrotoxic prevention of diet-induced insulin resistance by 3,5-diiodo-L-thyronine in rats. Diabetes 60 2730-2739. (doi:10.2337/db11-0207)

Del Viscovo A, Secondo A, Esposito A, Goglia F, Moreno M \& Canzoniero LM 2012 Intracellular and plasma membrane-initiated pathways involved in the $\left[\mathrm{Ca}^{2+}\right]_{\mathrm{i}}$ elevations induced by iodothyronines $\left(\mathrm{T}_{3}\right.$ and $\left.\mathrm{T}_{2}\right)$ in pituitary GH3 cells. American Journal of Physiology. Endocrinology and Metabolism 302 E1419-E1430. (doi:10.1152/ajpendo.00389.2011)

Dumas P, Autissier N, Loireau A \& Michel R 1982 Effects of 3,5,3'triiodothyroacetic acid (TRIAC) on protein metabolism of genetically obese or non-obese Zucker rats. Comptes Rendus des Séances de la Société de Biologie et de Ses Filiales 176 178-183. http://joe.endocrinology-journals.org DOI: 10.1530/JOE-13-0573
() 2014 Society for Endocrinology Printed in Great Britain 
Farwell AP, Lynch RM, Okulicz WC, Comi AM \& Leonard JL 1990 The actin cytoskeleton mediates the hormonally regulated translocation of type II iodothyronine $5^{\prime}$-deiodinase in astrocytes. Journal of Biological Chemistry 265 18546-18553.

Farwell AP, Dubord-Tomasetti SA, Pietrzykowski AZ \& Leonard JL 2006 Dynamic nongenomic actions of thyroid hormone in the developing rat brain. Endocrinology 147 2567-2574. (doi:10.1210/en.2005-1272)

Flamant F \& Samarut J 2003 Thyroid hormone receptors: lessons from knockout and knock-in mutant mice. Trends in Endocrinology and Metabolism 14 85-90. (doi:10.1016/S1043-2760(02)00043-7)

Forman BM, Casanova J, Raaka BM, Ghysdael J \& Samuels HH 1992 Halfsite spacing and orientation determines whether thyroid hormone and retinoic acid receptors and related factors bind to DNA response elements as monomers, homodimers, or heterodimers. Molecular Endocrinology 6 429-442. (doi:10.1210/mend.6.3.1316541)

Frascarelli S, Ghelardoni S, Chiellini G, Vargiu R, Ronca-Testoni S, Scanlan TS, Grandy DK \& Zucchi R 2008 Cardiac effects of trace amines: pharmacological characterization of trace amine associated receptors. European Journal of Pharmacology 587 231-236. (doi:10.1016/j.ejphar.2008.03.055)

Galo MG, Uñates LE \& Farías RN 1981 Effect of membrane fatty acid composition on the action of thyroid hormone on $\left(\mathrm{Ca}^{2+}+\mathrm{Mg}^{2+}\right)$ adenosine triphosphatase from rat erythrocyte. Journal of Biological Chemistry 256 7113-7114.

García GC, Jeziorski MC, Valverde RC \& Orozco A 2004 Effects of iodothyronines on the hepatic outer-ring deiodinating pathway in killifish. General and Comparative Endocrinology 135 201-209. (doi:10.1016/j.ygcen.2003.09.010)

Gerhart-Hines Z, Rodgers JT, Bare O, Lerin C, Kim SH, Mostoslavsky R, Alt FW, Wu Z \& Puigserver P 2007 Metabolic control of muscle mitochondrial function and fatty acid oxidation through SIRT1/ PGC-1alpha. EMBO Journal 26 1913-1923.

Gnoni GV, Rochira A, Leone A, Damiano F, Marsigliante S \& Siculella L 2012 3,5,3'triiodo-L-thyronine induces SREBP-1 expression by nongenomic actions in human HEP G2 cells. Journal of Cellular Physiology 227 2388-2397.

Goglia F 2005 Biological effects of 3,5-diiodothyronine $\left(\mathrm{T}_{2}\right)$. Biochemistry 70 164-172.

Goglia F, Lanni A, Barth J \& Kadenbach B 1994 Interaction of diiodothyronines with isolated cytochrome $c$ oxidase. FEBS Letters 346 295-298. (doi:10.1016/0014-5793(94)00476-5)

Goldberg IJ, Huang LS, Huggins LA, Yu S, Nagareddy PR, Scanlan TS \& Ehrenkranz JR 2012 Thyroid hormone reduces cholesterol via a non-LDL receptor-mediated pathway. Endocrinology 153 5143-5149. (doi:10.1210/en.2012-1572)

Grasselli E, Voci A, Canesi L, De Matteis R, Goglia F, Cioffi F, Fugassa E, Gallo G \& Vergani L 2011a Direct effects of iodothyronines on excess fat storage in rat hepatocytes. Journal of Hepatology 54 1230-1236. (doi:10.1016/j.jhep.2010.09.027)

Grasselli E, Voci A, Canesi L, Goglia F, Ravera S, Panfoli I, Gallo G \& Vergani L $2011 b$ Non-receptor-mediated actions are responsible for the lipid-lowering effects of iodothyronines in $\mathrm{FaO}$ rat hepatoma cells. Journal of Endocrinology 21 59-69. (doi:10.1530/JOE-11-0074)

Gullberg H, Rudling M, Forrest D, Angelin B \& Vennstrom B 2000 Thyroid hormone receptor $\beta$-deficient mice show complete loss of the normal cholesterol 7a-hydroxylase (CYP7A) response to thyroid hormone but display enhanced resistance to dietary cholesterol. Molecular Endocrinology 14 1739-1749. (doi:10.1210/mend.14.11.0548)

Gullberg H, Rudling M, Salto C, Forrest D, Angelin B \& Vennstrom B 2002 Requirement for thyroid hormone receptor $\beta$ in $T_{3}$ regulation of cholesterol metabolism in mice. Molecular Endocrinology 16 1767-1777. (doi:10.1210/me.2002-0009)

Hackenmueller SA, Marchini M, Saba A, Zucchi R \& Scanlan TS 2012 Biosynthesis of 3 iodothyronamine (T1AM) is dependent on the sodium-iodide symporter and thyroperoxidase but does not involve

http://joe.endocrinology-journals.org DOI: $10.1530 /$ JOE-13-0573
() 2014 Society for Endocrinology Printed in Great Britain extrathyroidal metabolism of $\mathrm{T}_{4}$. Endocrinology 153 5659-5667. (doi:10.1210/en.2012-1254)

Hart ME, Suchland KL, Miyakawa M, Bunzow JR, Grandy DK \& Scanlan TS 2006 Trace amine-associated receptor agonists; synthesis and evaluation of thyronamines and related analogues. Journal of Medicinal Chemistry 49 1101-1112. (doi:10.1021/jm0505718)

Hoefig CS, Köhrle J, Brabant G, Dixit K, Yap J, Strasburger CJ \& Wu Z 2011 Evidence for extrathyroidal formation of 3-iodothyronamine in humans as provided by a novel monoclonal antibody-based chemiluminescent serum immunoassay. Journal of Clinical Endocrinology and Metabolism 98 1864-1872. (doi:10.1210/jc.2010-2680)

Hoefig CS, Renko K, Piehl S, Scanlan TS, Bertoldi M, Opladen T, Hoffmann GF, Klein J, Blankenstein O, Sc weizer U et al. 2012 Does the aromatic L-amino acid decarboxylase contribute to thyronamine biosynthesis? Molecular and Cellular Endocrinology 349 195-201. (doi:10.1016/j.mce.2011.10.024)

Horn S, Kersseboom S, Mayerl S, Müller J, Groba C, Trajkovic-Arsic M, Ackermann T, Visser TJ \& Heuer H 2013 Tetrac can replace thyroid hormone during brain development in mouse mutants deficient in the thyroid hormone transporter mct8. Endocrinology 154 968-679. (doi:10.1210/en.2012-1628)

Ianculescu AG, Giacomini KM \& Scanlan TS 2009 Identification and characterization of 3-iodothyronamine intracellular transport. Endocrinology 150 1991-1999. (doi:10.1210/en.2008-1339)

Ianculescu AG, Friesema EC, Visser TJ, Giacomini KM \& Scanlan TS 2010 Transport of thyroid hormones is selectively inhibited by 3-iodothyronamine. Molecular BioSystems 6 1403-1410. (doi:10.1039/b926588k)

Incerpi S, De Vito P, Luly P, Spagnuolo S \& Leoni S 2002 Short-term effects of thyroid hormones and 3,5-diiodothyronine on membrane transport systems in chick embryo hepatocytes. Endocrinology 143 1660-1668. (doi:10.1210/endo.143.5.8767)

Incerpi S, Scapin S, D’Arezzo S, Spagnuolo S \& Leoni S 2005 Short-term effects of thyroid hormone in prenatal development and cell differentiation. Steroids 70 434-443. (doi:10.1016/j.steroids.2005. 02.009)

Irrcher I, Walkinshaw DR, Sheehan TE \& Hood DA 2008 Thyroid hormone $\left(\mathrm{T}_{3}\right)$ rapidly activates $\mathrm{p} 38$ and AMPK in skeletal muscle in vivo. Journal of Applied Physiology 104 178-185. (doi:10.1152/japplphysiol. 00643.2007)

Johansson L, Rudling M, Scanlan TS, Lundasen T, Webb P, Baxter J, Angelin B \& Parini P 2005 Selective thyroid receptor modulation by GC-1 reduces serum lipids and stimulates steps of reverse cholesterol transport in euthyroid mice. PNAS 102 10297-10302. (doi:10.1073/ pnas.0504379102)

Klieverik LP, Foppen E, Ackermans MT, Serlie MJ, Sauerwein HP, Scanlan TS, Grandy DK, Fliers E \& Kalsbeek A 2009 Central effects of thyronamines on glucose metabolism in rats. Journal of Endocrinology 201 377-386. (doi:10.1677/JOE-09-0043)

Kunitake JM, Hartman N, Henson LC, Lieberman J, Williams DE, Wong M \& Hershman JM 1989 3,5,3'-Triiodothyroacetic acid therapy for thyroid hormone resistance. Journal of Clinical Endocrinology and Metabolism 69 461-466. (doi:10.1210/jcem-69-2-461)

Ladenson PW 2011 Thyroid hormone analogues: ready for prime time. Thyroid 21 101-102. (doi:10.1089/thy.2010.2100.com1)

Lagouge M, Argmann C, Gerhart-Hines Z, Meziane H, Lerin C, Daussin F, Messadeq N, Milne J, Lambert P, Elliot P et al. 2006 Resveratrol improves mitochondrial function and protects against metabolic disease by activating SIRT1 and PGC-1alpha. Cell 127 1109-1122.

Lanni A, Moreno M, Cioffi M \& Goglia F 1992 Effect of 3,3'-diiodothyronine and 3,5-diiodothyronine on rat liver oxidative capacity. Molecular and Cellular Endocrinology 86 143-148. (doi:10.1016/ 0303-7207(92)90138-V)

Lanni A, Moreno M, Cioffi M \& Goglia F 1993 Effect of 3,3'-diiodothyronine and 3,5-di-iodothyronine on rat liver mitochondria. Journal of Endocrinology 136 59-64. (doi:10.1677/joe.0.1360059) 
Lanni A, Moreno M, Horst C, Lombardi A \& Goglia F 1994 Specific binding sites for 3,3' -diiodo-L-thyronine $\left(3,3^{\prime}-\mathrm{T}_{2}\right)$ in rat liver mitochondria. FEBS Letters 351 237-240. (doi:10.1016/0014-5793(94)00840-X)

Lanni A, Moreno M, Lombardi A \& Goglia F 1996 Calorigenic effect of diiodothyronines in the rat. Journal of Physiology 494 831-837.

Lanni A, Moreno M, Lombardi A \& Goglia F 1998 3,5-Diiodo-L-thyronine and 3,5,3'-triiodo-L-thyronine both improve the cold tolerance of hypothyroid rats, but possibly via different mechanisms. Pflügers Archiv: European Journal of Physiology 436 407-414. (doi:10.1007/ s004240050650)

Lanni A, Moreno M, Lombardi A, de Lange P, Silvestri E, Ragni M, Farina P, Chieffi Baccari G, Fallahi P, Antonelli A et al. 2005 3,5-Diiodo-L-thyronine powerfully reduces adiposity in rats by increasing the burning of fats. FASEB Journal 19 1552-1554.

Leary SC, Barton KN \& Ballantyne JS 1996 Direct effects of 3,5,3'triiodothyronine and 3,5-diiodothyronine on mitochondrial metabolism in the goldfish Carassius auratus. General and Comparative Endocrinology 104 61-66. (doi:10.1006/gcen.1996.0141)

Lerman J 1956 The activity of dl-tribromthyronine. Journal of Clinical Endocrinology and Metabolism 16 1395-1397. (doi:10.1210/ jcem-16-10-1395)

Lin HY, Sun M, Lin C, Tang HY, London D, Shih A, Davis FB \& Davis PJ $2009 a$ Androgen induced human breast cancer cell proliferation is mediated by discrete mechanisms in estrogen receptor- $\alpha$-positive and -negative breast cancer cells. Journal of Steroid Biochemistry and Molecular Biology 113 182-188. (doi:10.1016/j.jsbmb.2008.12.010)

Lin HY, Sun M, Tang HY, Lin C, Luidens MK, Mousa SA, Incerpi S, Drusano GL,

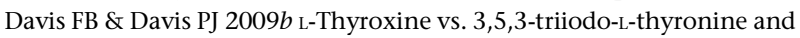
cell proliferation: activation of mitogen-activated protein kinase and phosphatidylinositol 3-kinase. American Journal of Physiology. Cell Physiology 296 C980-C991. (doi:10.1152/ajpcell.00305.2008)

Little AG, Kunisue T, Kannan K \& Seebacher F 2013 Thyroid hormone actions are temperature-specific and regulate thermal acclimation in zebrafish (Danio rerio). BMC Biology 26 11-26. (doi:10.1186/17417007-11-26)

Lombardi A, De Matteis R, Moreno M, Napolitano L, Busiello RA, Senese R, de Lange P, Lanni A \& Goglia F 2012 Responses of skeletal muscle lipid metabolism in rat gastrocnemius to hypothyroidism and iodothyronine administration: a putative role for FAT/CD36. American Journal of Physiology. Endocrinology and Metabolism 303 E1222-E1233. (doi:10.1152/ajpendo.00037.2012)

Luongo C, Trivisano L, Alfano F \& Salvatore D 2013 Type 3 deiodinase and consumptive hypothyroidism: a common mechanism for a rare disease. Frontiers in Endocrinology 115 1-7. (doi:10.3389/fendo.2013. 00115)

Maia AL, Goemann IM, Meyer EL \& Wajner SM 2011 Deiodinases: the balance of thyroid hormone: type 1 iodothyronine deiodinase in human physiology and disease. Journal of Endocrinology 209 283-297. (doi:10.1530/JOE-10-0481)

Mangiullo R, Gnoni A, Damiano F, Siculella L, Zanotti F, Papa S \& Gnoni GV 2010 3,5-Diiodo-L-thyronine upregulates rat-liver mitochondrial $\mathrm{F}(\mathrm{o}) \mathrm{F}(1)$-ATP synthase by GA-binding protein/nuclear respiratory factor-2. Biochimica et Biophysica Acta 1797 233-240. (doi:10.1016/j.bbabio.2009.10.009)

Manni ME, De Siena G, Saba A, Marchini M, Dicembrini I, Bigagli E, Cinci L, Lodovici M, Chiellini MG, Zucchi R et al. 2012 3-Iodothyronamine: a modulator of the hypothalamus-pancreas-thyroid axes in mice. British Journal of Pharmacology 166 650-658. (doi:10.1111/j.1476-5381. 2011.01823.x

Manni ME, De Siena G, Saba A, Marchini M, Landucci E, Gerace E, Zazzeri M, Mussili C, Pellegrini-Giampietro D, Matucci R et al. 2013 Pharmacological effects of 3-iodothyronamine (T1AM) in mice include facilitation and memory acquisition and retention and reduction of pain threshold. British Journal of Pharmacology 168 354-362. (doi:10.1111/j.1476-5381.2012.02137.x)

http://joe.endocrinology-journals.org DOI: $10.1530 / J O E-13-0573$
() 2014 Society for Endocrinology Printed in Great Britain
Medina-Gomez G, Hernandez A, Calvo RM, Martin E \& Obregon MJ 2003 Potent thermogenic action of triiodothyroacetic acid in brown adipocytes. Cellular and Molecular Life Sciences $601957-1967$. (doi:10.1007/s00018-003-3158-9)

Medina-Gomez G, Calvo MR \& Obregon MJ $2004 \mathrm{~T}_{3}$ and Triac inhibit leptin secretion and expression in brown and white rat adipocytes. Biochimica et Biophysica Acta 1682 38-47. (doi:10.1016/j.bbalip.2004.01.007)

Mendoza A, Navarrete-Ramírez P, Hernández-Puga G, Villalobos P, Holzer G, Renaud JP, Laudet V \& Orozco A 2013 3,5- $\mathrm{T}_{2}$ is an alternative ligand for the thyroid hormone receptor $\beta 1$. Endocrinology 154 2948-2958. (doi:10.1210/en.2013-1030)

Moeller LC \& Broecker-Preuss M 2011 Transcriptional regulation by nonclassical action of thyroid hormone. Thyroid Research $\mathbf{4}$ (Suppl 1) S6. (doi:10.1186/1756-6614-4-S1-S6)

Moeller LC, Dumitrescu AM \& Refetoff S 2005 Cytosolic action of thyroid hormone leads to induction of hypoxia-inducible factor- 1 and glycolytic genes. Molecular Endocrinology 19 2955-2963. (doi:10.1210/ me.2004-0542)

Mollica MP, Lionetti L, Moreno M, Lombardi A, de Lange P, Antonelli A, Lanni A, Cavaliere G, Barletta A \& Goglia F 2009 3,5-Diiodo-Lthyronine, by modulating mitochondrial functions, reverses hepatic fat accumulation in rats fed a high-fat diet. Journal of Hepatology $\mathbf{5 1}$ 363-370. (doi:10.1016/j.jhep.2009.03.023)

Moreno M, Kaptein E, Goglia F \& Visser TJ 1994 Rapid glucuronidation of tri- and tetraiodothyroacetic acid to ester glucuronides in human liver and to ether glucuronides in rat liver. Endocrinology 135 1004-1009. (doi:10.1210/endo.135.3.8070342)

Moreno M, Lombardi A, Beneduce L, Silvestri E, Pinna G, Goglia F \& Lanni A 2002 Are the effects of $T_{3}$ on resting metabolic rate in euthyroid rats entirely caused by $\mathrm{T}_{3}$ itself? Endocrinology 143 504-510. (doi:10.1210/endo.143.2.8613)

Moreno M, Silvestri E, De Matteis R, de Lange P, Lombardi A, Glinni D, Senese R, Cioffi F, Salzano AM, Scaloni A et al. 2011 3,5-Diiodo-Lthyronine prevents high-fat-diet-induced insulin resistance in rat skeletal muscle through metabolic and structural adaptations. FASEB Journal 25 3312-3324. (doi:10.1096/fj.11-181982)

Navarrete-Ramirez P, Luna M, Valverde RC \& Orozco A 2014 3,5-T 2 stimulates tilapia growth through an alternate isoform of thyroid hormone receptor $\beta 1$. Journal of Molecular Endocrinology 52 1-9. (doi:10.1530/JME-13-0145)

Oetting A \& Yen PM 2007 New insights into thyroid hormone action. Best Practice \& Research. Clinical Endocrinology \& Metabolism 21 193-208. (doi:10.1016/j.beem.2007.04.004)

Orozco A, Valverde RC, Olvera A \& García GC 2012 Iodothyronine deiodinases: a functional and evolutionary perspective. Journal of Endocrinology 215 207-219. (doi:10.1530/JOE-12-0258)

Pascual A \& Aranda A 2013 Thyroid hormone receptors, cell growth and differentiation. Biochimica et Biophysica Acta 1830 3908-3916. (doi:10.1016/j.bbagen.2012.03.012)

Piehl S, Heberer T, Balizs G, Scanlan TS, Smits R, Koksch B \& Köhrle J 2008 Thyronamines are isozyme-specific substrates of deiodinases. Endocrinology 149 3037-3045. (doi:10.1210/en.2007-1678)

Pinna G, Meinhold H, Hiedra L, Thoma R, Hoell T, Gräf KJ, StoltenburgDidinger G, Eravci M, Prengel H, Brödel O et al. 1997 Elevated 3,5-diiodothyronine concentrations in the sera of patients with nonthyroidal illnesses and brain tumors. Journal of Clinical Endocrinology and Metabolism 82 1535-1542. (doi:10.1210/jcem.82.5.3939)

Pittman CS, Shimizu T, Burger A \& Chambers JB Jr 1980 The nondeiodinative pathways of thyroxine metabolism: 3,5,3',5-tetraiodothyroacetic acid turnover in normal and fasting human subjects. Journal of Clinical Endocrinology and Metabolism 50 712-716. (doi:10.1210/ jcem-50-4-712)

Pramfalk C, Pedrelli M \& Parini P 2011 Role of thyroid receptor $\beta$ in lipid metabolism. Biochimica et Biophysica Acta 1812 929-937. (doi:10.1016/ j.bbadis.2010.12.019) 
Rochira A, Damiano F, Marsigliante S, Gnoni GV \& Siculella L 2013 3,5-Diiodo-1-thyronine induces SREBP-1 proteolytic cleavage block and apoptosis in human hepatoma (Hepg2) cells. Biochimica et Biophysica Acta 1831 1679-1688.

Rodgers JT, Lerin C, Haas W, Gygi SP, Spiegelman BM \& Puigserver P 2005 Nutrient control of glucose homeostasis through a complex of PGC-1alpha and SIRT1. Nature 434 113-118.

Ruderman NB, Carling D, Prentki M \& Cacicedo 2013 AMPK, insulin resistance, and the metabolic syndrome. Journal of Clinical Investigation 123 2764-2772.

Saba A, Chiellini G, Frascarelli S, Marchini M, Chelardoni S, Rafaelli A, Tonacchera M, Vitti P, Scanlan TS \& Zucchi R 2010 Tissue distribution and cardiac metabolism of 3-iodothyronamine. Endocrinology 151 5063-5073. (doi:10.1210/en.2010-0491)

Scanlan TS, Suchland KL, Hart ME, Chiellini G, Huang Y, Kruzich PJ, Frascarelli S, Crossley DA, Bunzow JR, Ronca-Testoni S et al. 2004 3-Iodothyronamine is an endogenous and rapid-acting derivative of thyroid hormone. Nature Medicine 10 638-642. (doi:10.1038/nm1051)

Scapin S, Leoni S, Spagnuolo S, Fiore AM \& Incerpi S 2009 Short-term effects of thyroid hormones on $\mathrm{Na}^{+}-\mathrm{K}^{+}$-ATPase activity of chick embryo hepatocytes during development: focus on signal transduction. American Journal of Physiology. Cell Physiology 296 C4-C12. (doi:10.1152/ajpcell.90604.2007)

Schueler PA, Schwartz HL, Strait KA, Mariash CN \& Oppenheimer JH 1990 Binding of 3,5,3'-triiodothyronine $\left(\mathrm{T}_{3}\right)$ and its analogs to the in vitro translational products of c-erbA protooncogenes: differences in the affinity of the $\alpha$ - and $\beta$-forms for the acetic acid analog and failure of the human testis and kidney $\alpha-2$ products to bind $\mathrm{T}_{3}$. Molecular Endocrinology 4 227-234. (doi:10.1210/mend-4-2-227)

Shang G, Gao P, Zhao Z, Chen Q, Jiang T, Zhang N \& Li H 2013 3,5-DiiodoL-thyronine ameliorates diabetic nephropathy in streptozotocininduced diabetic rats. Biochimica et Biophysica Acta 1832 674-684.

Sherman SI \& Ladenson PW 1992 Organ-specific effects of tiratricol: a thyroid hormone analog with hepatic, not pituitary, superagonist effects. Journal of Clinical Endocrinology and Metabolism 75 901-905. (doi:10.1210/jcem.75.3.1517383)

Shoemaker TJ, Kono T, Mariash CN \& Evans-Molina C 2012 Thyroid hormone analogues for the treatment of metabolic disorders: new potential for unmet clinical needs? Endocrine Practice 18 954-964. (doi:10.4158/EP12086.RA)

Siegrist-Kaiser C \& Burger AG 1994 Modification of the side chain of thyroid hormones. In Thyroid Hormone Metabolism, pp 17-198. Eds SY Wu \& TJ Visser TJ. Boca Raton: CRC Press, Inc.

Siegrist-Kaiser CA, Juge-Aubry C, Tranter MP, Ekenbarger DM \& Leonard JL 1990 Thyroxine-dependent modulation of actin polymerization in cultured astrocytes. A novel, extranuclear action of thyroid hormone. Journal of Biological Chemistry 265 5296-5302.

Silvestri E, Cioffi F, Glinni D, Ceccarelli M, Lombardi A, de Lange P, Chambery A, Severino V, Lanni A, Goglia F et al. 2010 Pathways affected by 3,5-diiodo-L-thyronine in liver of high fat-fed rats: evidence from two-dimensional electrophoresis, blue-native PAGE, and mass spectrometry. Molecular BioSystems 6 2256-2271. (doi:10.1039/ c0mb00040j)

Snead AN, Miyakawa M, Tan ES \& Scanlan TS 2008 Trace amine-associated receptor 1 (TAAR1) is activated by amiodarone metabolites. Bioorganic \& Medicinal Chemistry Letters 18 5920-5922. (doi:10.1016/j.bmcl.2008. 08.013)

Tan ES, Miyakawa M, Bunzow JR, Grandy DK \& Scanlan TS 2007 Exploring the structure-activity relationship of the ethylamine portion of 3-iodothyronamine for rat and mouse trace amine-associated receptor 1. Journal of Medicinal Chemistry 50 2787-2798. (doi:10.1021/ jm0700417)

Tan ES, Groban ES, Jacobson MP \& Scanlan TS 2008 Toward deciphering the code to aminergic $G$ protein-coupled receptor drug design. Chemistry \& Biology 15 343-353. (doi:10.1016/j.chembiol.2008.03.004)

Tata JR 2013 The road to nuclear receptors of thyroid hormone. Biochimica et Biophysica Acta 1830 3860-3866.

Visser TJ 1990 Importance of deiodination and conjugation in the hepatic metabolism of thyroid hormone. In The Thyroid Gland, pp 255-283. Ed. MA Greer. New York: Raven Press.

Visser TJ 2013 Thyroid hormone transporters and resistance. Endocrine Development 24 1-10. (doi:10.1159/000343695)

Webb P 2010 Thyroid hormone receptor and lipid regulation. Current Opinion in Investigational Drugs 11 1135-1142.

Weitzel JM \& Alexander Iwen K 2011 Coordination of mitochondrial biogenesis by thyroid hormone. Molecular and Cellular Endocrinology 342 1-7. (doi:10.1016/j.mce.2011.05.009)

Williams GR 2000 Cloning and characterization of two novel thyroid hormone receptor $\beta$ isoforms. Molecular and Cellular Biology 20 8329-8342. (doi:10.1128/MCB.20.22.8329-8342.2000)

Wrutniak C, Cassar-Malek I, Marchal S, Rascle A, Heusser S, Keller JM, Fléchon J, Dauça M, Samarut J, Ghysdael J et al. 1995 A 43-kDa protein related to c-Erb $\mathrm{A} \alpha 1$ is located in the mitochondrial matrix of rat liver. Journal of Biological Chemistry 270 16347-16354. (doi:10.1074/jbc.270. 27.16347)

Wrutniak-Cabello C, Casas F \& Cabello G 2001 Thyroid hormone action in mitochondria. Journal of Molecular Endocrinology 26 67-77. (doi:10.1677/jme.0.0260067)

Zucchi R, Chiellini G, Scanlan TS \& Grandy DK 2006 Trace amineassociated receptors and their ligands. British Journal of Pharmacology 149 967-978. (doi:10.1038/sj.bjp.0706948)

Received in final form 13 January 2014

Accepted 21 January 2014

Accepted Preprint published online 24 January 2014 http://joe.endocrinology-journals.org DOI: 10.1530/JOE-13-0573
() 2014 Society for Endocrinology Printed in Great Britain
Published by Bioscientifica Ltd. 